\title{
Fen ve Teknoloji Dersine İlişkin Piaget'in Soyut İşlemler Döneminde Kazanılması Beklenen Becerilerin Gerçekleşme Durumunun İncelenmesi*
}

\author{
Doç. Dr. Murat DEMİRBAŞ** \\ Kırıkkale Üniversitesi, Eğitim Fakültesi, İlköğretim Bölümü Fen Bilgisi Eğitimi Ana Bilim \\ Dalı 71450 Yahşihan / Kırıkkale / Türkiye \\ Nurcan ERTUĞRUL \\ Kırıkkale Üniversitesi, Eğitim Fakültesi, İlköğretim Bölümü Fen Bilgisi Eğitimi Ana Bilim \\ Dalı 71450 Yahşihan / Kırıkkale / Türkiye
}

\section{Özet}

Öğretim programları hazırlanırken öğrencilerin zihinsel seviyeleri ön plana çıkarılmalı ve öğrencilerin bulundukları yaşın gerektirdiği zihinsel süreçlere göre aktiviteler geliştirilmelidir. Bireylerin zihinsel gelişimleri hakkında önemli bir teori ortaya koyan J. Piaget, kişilerin sahip olması gereken becerileri ayrıntılı bir biçimde dönemlerine göre açıklamıştır. Yapılan çalışmada da öğrencilerin sahip olması gereken soyut işlem becerilerinin, ilköğretim öğrencileri tarafından hangi düzeyde gerçekleştirildiği araştırılmıştır. Bu amaçla nitel araştırma modellerinden durum * Bu çalışmanın bir kısmı X. Ulusal Fen ve Matematik Alanları Eğitimi kongresinde bildiri olarak sunulmuştur. 
çalışması modeli kullanılmıştır. Araştırmaya 4., 5., 6. ve 7. sınıf öğrencilerinden 300 öğrenci katılmıştır. Öğrencilerin soyut işlem dönemindeki becerileri gerçekleştirme durumlarını ortaya koymak için, "Soyut İşlemler Dönemi Beceri Testi (SIDBT)" adı ile bir ölçme aracı geliştirilmiştir. Ölçme aracının geçerlik ve güvenirlik çalışması araştırmacılar tarafından yapılmıştır. Araştırma sonuçlarına göre, öğrencilerin soyut işlem dönemine ilişkin becerileri gerçekleştirme durumlarının düşük düzeyde olduğu, yine en düşük becerinin hipotez kurma becerisinde olduğu görülmüştür. Araştırmada bulgulara yönelik önerilere yer verilmiştir.

Anahtar Kelimeler: Fen ve teknoloji eğitimi; Soyut işlemler; Eğitim programı, Fen ve teknoloji dersi; İlköğretim öğrencileri.

\title{
An Investigation into the Realization of Skills in the Science and Technology Lessons Expected to be Acquired in Piaget's Abstract Operations Stage
}

\begin{abstract}
When preparing educational curricula, students' cognitive levels should be considered in the first place and activities appropriate for the cognitive processes of the students' age level should be developed. J. Piaget who put forward a critical theory on individuals' cognitive development explained in detail the skills that individuals should possess in terms of specific periods. This present study aims to understand to what extent primary school students realize the expected abstract operation skills. To this end, the case study model, as one of the qualitative research models, was applied. 300 students from the 4th, 5th, 6th and 7 th grades participated in the study. In order to demonstrate students' achievement level of the abstract operations skills, a measurement instrument called the "Abstract Operations Period Skills Test" (AOPST) was developed. The reliability and validity of the instrument was tested by the researchers. According to the results of the study, students' achievement of skills specific to the abstract operations stage was found to be at a low level and the poorest skill was determined to be hypothesis formation. Suggestions related to the findings are also provided in this present study.
\end{abstract}

Keywords: Science and technology education; Abstract operations; Educational program; Science and technology lesson, Elemen- 
tary school students.

\section{Extended Summary}

\section{Purpose}

According to Piaget's learning theory, cognitive development is separated into four periods: sensori-motor (0-2 years), pre-operational (2-7 years), concrete operations (7-11 years) and abstract operations (11 years and older). The skills required by each cognitive development period differ in terms of factors such as the child's experiences, environmental factors, and readiness level (Ömercikoğlu, 2006).

To Piaget, the abstract operations period is the highest level of cognitive development. Individuals can perform the concepts of this level in an abstract way. Piaget describes this stage as the formal operations period (Şimşek, 2007). In this period, abstract thinking starts. The solution to a problem is not restricted to concrete thinking. The individual forms relationships between the variables in the problem. Thinking through deduction and induction is observed (Senemoğlu, 2011).

Science education studies in the recent years emphasize that the constructivist learning approach provides a beneficial and functional framework for realizing the aims of science education and brings new applications to teaching (MEB, 2006). In the constructivist approach, it is expected that students are aware of the basic concepts underlying the lessons (Malatyalı and Y1lmaz, 2010). The fact that science and tech- 
nology lesson incorporates a lot of abstract concepts, more complex and higher-level cognitive operations (Özsevgeç, 2006) increases the necessity for students to possess skills related to abstract operations.

An evaluation of the previous literature shows that in order to realize concept learning, remove misconceptions and increase students' science achievement, exhibition of the behaviors expected for abstract operations periods gains importance. Therefore, the present study aims to analyze 5th, 6th and 7th graders' level of exhibiting abstract operations skills.

\section{Methods}

The case study approach, which is a qualitative research method, was applied in the present research. The method is an acknowledged way of addressing scientific questions. Case study is defined as a method which analyzes one or more events, the environment, program, social group or interrelated systems (Büyüköztürk et al., 2010).

\section{Results}

According to the results, students' level of performing skills related to the abstract operations period was at a low level. This finding is in line with Kilcan and Yazgan's (2010) finding that the majority of the 7th and 8th graders are in the concrete operations stage.

The results also point out that the poorest skill is hypothetical thinking. Students also have difficulty in forming research questions and hypotheses. Hypothesis formation is at the same time included in the experimental skills component of scientific research skills 
An analysis of the science and technology lesson's course books reveals that research questions are addressed in 6 activities in the 4th grade, in 7 activities in the 5th grade, in 11 activities in the 6th grade and in 14 activities in the 7th grade. The student is asked to form a research question only in the 6th grade and in one activity. Hypothesis is briefly defined in the 5th grade course book and formed in 3 activities. In the 6th grade, 4 hypothesis situations are given while in the 7 th grade 3 activities contain hypothesis situations. Again in the 6th grade students are asked to form hypotheses only in one activity. The results reveal that the course books do not emphasize the development of critical thinking skills.

Özcan and Oluk's (2007) study analyzing the questions used in primary school science education classes demonstrate that questions addressing hypothetical thinking skills have a frequency of less than $\% 1$. This finding lends support to the view that hypothetical thinking skills are not supported by written exam questions, either.

Determination of the variables is the second least developed skill following hypothetical thinking. Students showed the lowest amount of success in the determination of variables. The third least developed skill is correlational thinking. This was followed by proportional, probabilistic and combinatorial thinking. Çeken and Ayas' (2010) study highlights the importance of proportional thinking for science, mathematics and social sciences classes. In the same study it was concluded that the timing of gains related to ratio and proportion and that of 
units are not compatible with each other. Support for proportional thinking is also important in terms of other disciplines.

\section{Conclusion}

Teachers hold responsibility for the development of abstract operations period skills in students. In the first place, teachers should be knowledgeable about what cognitive development is, at what level their students are, and what skills are required at this developmental level. When planning educational activities, giving place to activities promoting these skills is of high significance.

Attention should also be paid so that the written exam questions should support skills expected from students. Science and technology course books should be analyzed and their contributions to skills development should be validated.

\section{Giriş}

Bireyin çevresindeki dünyayı anlama ve öğrenmesini sağlayan, aktif zihinsel faaliyetlerdeki gelişime bilişsel gelişim adı verilmektedir. Bilişsel gelişim; bebeklikten yetişkinliğe kadar, bireyin çevreyi, dünyayı anlama yollarının daha kompleks ve etkili hale gelmesi sürecidir (Senemoğlu, 2011).

Zihin gelişimini açıklamada başarılı olmuş en önemli kuramlardan biri Jean Piaget tarafindan ortaya atılan (1896-1980) zihinsel yapılanma kuramıdır (Kılcal ve Yazgan, 2010). Piaget zihinsel gelişmeyi 
yaşa bağlı bir süreç olarak görür ve doğuştan yetişkinliğe doğru bir gelişim gösterdiğini savunur (YÖK/Dünya Bankası, 1997). Piaget, bilişsel gelişimi biyolojik ilkelerle açıklamıştır. Piaget'e göre gelişim kalıtım ve çevrenin etkileşiminin bir sonucudur. Bilişsel gelişimi etkileyen ilkeleri de şöyle belirlemektedir. Olgunlaşma, yaşantı, uyum, örgütleme ve dengeleme (Senemoğlu, 2011). Bireyin bilişsel gelişimi bu faktörlerin etkisiyle şekillenmektedir.

Bilişsel gelişim olgunlaşma ve yaşantı kazanma arasındaki etkileşimin bir ürünüdür. Piaget bilişsel gelişimi dünyayı öğrenme yolunda bir denge, dengesizlik yeni bir denge süreci olarak görmektedir. Diğer bir deyişle alt düzeydeki bir dengeden üst düzeydeki bir dengeye ilerleme olarak tanımlamaktadır (Senemoğlu, 2011). Piaget'e göre her birey zihninde yaşantıları sonucunda oluşturduğu kendine özgü bir bilgi yapısına (şema) sahiptir. Her bireyin sahip olduğu bu şemalar çevreyle etkileşim sonucu sürekli olarak değişir ve gelişir (Çakıcı, 2010).

Öte yandan, öğretimin planlanmasında cevaplanması gereken en önemli soru öğrencinin amaçlanan ve planlanan eğitimi almaya elverişli bir bilişsel gelişim düzeyine sahip olup olmadığıdır. Eğer planlanan eğitim öğrenciye kazandırılacak davranışlar açısından çocuğun seviyesinin üzerinde ise çocuk başarısız olacaktır. Öğrencinin hangi yaşta hangi özelliklere sahip olduğunun bilinmesi, verilecek eğitimin hedefleri, içeriği ve kullanılacak yöntemlerin öğrencilerin düzeyine göre seçilmesine olanak sağlar. Bu nedenle, bilişsel gelişimin ne an- 
lama geldiğinin ve bilişsel gelişim dönemlerinin özelliklerinin bilinmesi önem taşımaktadır (Çepni, 2011).

Piaget'in öğrenme kuramına göre bilişsel gelişim; duyu-motor (0-2 yaş), işlem öncesi (2-7 yaş), somut işlemler (7-11 yaş) ve soyut işlemler (11 yaş ve üstü) olmak üzere dört döneme ayrılır. Her bilişsel gelişim döneminin getirdiği yetenekler, çocuğun geçirdiği yaşantı, çevresel faktörler, hazır bulunuşluk düzeyi gibi durumlara göre farklılık gösterebilmektedir (Ömercikoğlu, 2006).

Piaget, tüm çocukların bu gelişim aşamalarını sırasıyla geçirmesi gerektiğine inanmaktadır. Bireyin, bir gelişim dönemini atlayarak diğerine geçemeyeceği ifade edilmektedir (Senemoğlu, 2011). Piaget her ne kadar bilişsel gelişimi belirli yaşlara ayırmış olsa da dönem sınırları belirgin değildir. Bireyler bazen dönemler arasında uzun süreli geçişler yaşayabilmekte, bazen üst seviye, bazen de alt seviye davranışı sergileyebilmektedirler (Kilcal ve Yazgan, 2010).

Piaget'e göre soyut işlemler dönemi zihinsel gelişimin en üst noktasıdır. Bireyler bu seviyenin düşüncelerini soyut olarak gerçekleştirebilirler. Piaget bu dönemi formal operasyonel dönem olarak isimlendirmiştir (Şimşek, 2007). Bu dönemde artık soyut düşünme başlar. Bir problemin çözümü somut yollarla sınırlanmaz. Problemde bulunan değişkenler arasındaki ilişkileri bulur. Tümevarım ve tümdengelim yoluyla akıl yürütme gözlenir (Senemoğlu, 2011). Bu dönemin diğer bir düşünme özelliği de birleştirmeci (kombinasyonel) düşünmedir. Birkaç faktörün birlikte ele alınarak sorunun çözülmesi bu 
dönemde edinilir (Bacanlı, 2005). Bu dönemde bireyler varsayıma dayanan konularla başa çıkabilmektedirler (Çepni, Gökdere ve Özsevgeç, 2002).Yine bu dönemde zihinsel işlemler yapılabilir, hipotez geliştirilerek problemlere analitik çözümler bulunabilir (Bacanlı, 2005).

Piaget, formal operasyon dönem özelliklerini hipotetik düşünme, kombinezonlu düşünme, olasılıklı düşünme, değişkenleri belirleme ve kontrol etme, korelasyonel düşünme ve oranlı düşünme olmak üzere altı başlık altında toplamıştır (Çepni, 2011). Soyut işlemler (formal operasyonel ) döneminde bireylerde bulunması beklenen bu beceriler uygun öğretim yöntemleriyle geliştirilmelidir. Ayvacı ve Şahin (2009) öğrencilerin sorgulama yeteneklerinin onların bilişsel gelişimiyle paralel olarak gelişim gösterdiğini, bu bağlamda sorulan soruların bireylerin formal gelişim dönemlerine uygun olarak sorulmasının önemli ve gerekli olduğunu ifade etmişlerdir.

Soyut işlemler döneminin 11 yaşından itibaren başladığı düşünüldüğünde, ilköğretim 5, 6, 7 ve 8. sınıf öğrencileri bu dönem içinde bulunurlar. Günümüz bilgi ve teknoloji çağında, toplumların geleceği açısından fen ve teknoloji eğitiminin anahtar bir rol oynadığı açıkça görülmektedir. $\mathrm{Bu}$ nedenle, gelişmiş ülkeler başta olmak üzere bütün toplumlar sürekli olarak fen ve teknoloji eğitiminin kalitesini arttırma çabası içindedir (MEB, 2006). Piaget'in bilişsel gelişim teorisi çocuğun düşünce süreçlerini anlamaya önemli katkılarda bulunmuştur. Öğretmenler etkili bir fen eğitimi için öğrencilerinin hangi bilişsel gelişim seviyesinde olduklarını bilmelidirler (Çakıcı, 2010). Piaget kuramını 
bilen bir fen öğretmeni öğrencilerinin evreler arasında bir üste geçişini hızlandırabilir ve bilişsel gelişimi kolaylaştırabilir (YÖK/Dünya Bankas1, 1997).

Son yıllardaki fen eğitimi araştırmaları, fen eğitiminin amaçlarını gerçekleştirmede yapılandırıcı öğrenme yaklaşımının faydalı ve işlevsel bir çerçeve sağladığını ve öğretime de yeni uygulamalar getirdiğini vurgulamaktadır (MEB, 2006).Yapılandırıcı yaklaşımda öğrencilerin derslerin dayandığı disiplinlerin temel kavramlarını bilmeleri beklenmektedir (Malatyalı ve Yılmaz, 2010). Fen ve teknoloji dersinin birçok soyut kavramdan oluşması, diğer derslere göre daha karmaşık ve zihinsel faaliyetler içermesi (Özsevgeç, 2006), öğrencilerinin soyut işlemlerle ilgili becerilere sahip olma durumlarının gerekliliğini artırmaktadir.

Fen ve teknoloji ders kitapları incelendiğinde konu anlatımlarında öğrenme halkası yaklaşımına bağlı kalındığı görülmektedir. Öğrenme halkası, temelini Piaget'in zihinsel gelişim ve yapılandırmacılıktan alan aktif bir öğretim yaklaşımıdır (Ören ve Tezcan, 2009). Bu alanda yapılan çalışmalara bakıldığında, Piaget'in öğrenme kuramı üzerine yapılandırılmış öğrenme halkası yaklaşımı ile gerçekleştirilen öğretim etkinliklerinin, ilköğretim 7. sınıf öğrencileri üzerinde tutum ve başarı bakımından olumlu etkilere sahip olduğu görülmüştür (Ören ve Tezcan, 2009). Chrappetta (1976)'ın çalışmasında elde edilen sonuçlardan zihinsel gelişim ile fen başarısı arasında doğru orantılı bir ilişki olduğu belirlenmiştir. Özellikle formal döneme geçen öğrencilerin yüksek fen başarısı gösterdiği ifade edilmiştir (akt; Çepni, Gökdere 
ve Özsevgeç, 2002). Çapri ve Çelikkaleli (2005) çalışmalarında ilköğretim 7-11 yaş grubu öğrencilerinin korunum gelişim düzeylerini incelemişler, sayı, miktar, madde bakımından cinsiyete göre bir farkl1l1k bulamamışlardır. Yine Piaget'in öğrenme kuramı üzerine temellendirilen öğrenme döngüsü yaklaşımının öğrencilerdeki kavramsal değişimi sağladığını ifade eden pek çok çalışmanın olduğu görülmektedir (Baser, 2006; Fleener ve Marek; 1992; Marek, Askey ve Abraham, 2000; Türkmen ve Usta, 2007). Kavramsal değişim, öğrencilerin kavram yanılgılarından yani bilimsel olmayan bilgilerden bilimsel olarak kabul edilen bilgilere geçiş yapabilmelerini sağlayan bir yaklaşımdır (Malatyalı ve Yılmaz, 2010). Kavramsal değişimle anlamlı öğrenme gerçekleşmiş olur.

Yapılan araştırmalar değerlendirildiğinde kavram öğreniminin gerçekleşmesinde yanlış anlamaların giderilerek kavramsal değişimlerin sağlanmasında, öğrencilerin fen başarılarının artmasında, soyut işlem dönemlerinde gerçekleştirmesi beklenen davranışları sergilemelerinin önemi daha da artmaktadır. Bu nedenle araştırmada 4. 5. 6. ve 7. sınıf öğrencilerinin soyut işlemler dönemindeki becerileri gösterme durumlarının incelenmesi amaçlanmıştır.

\section{Yöntem}

Araştırmada nitel araştırma modellerinden durum çalışmaları modeli kullanılmıştır. Durum çalışmaları bilimsel sorulara cevap aramada kullanılan ayırt edici bir yaklaşım olarak kullanılmaktadır. Durum çalışmaları bir ya da daha fazla olayın, ortamın, programın, sosyal 
grubun ya da diğer birbirine bağlı sistemlerin incelendiği yöntem olarak tanımlanmaktadır (Büyüköztürk ve diğer., 2010).

Araştırmada amaçlı örnekleme yöntemlerinden ölçüt örnekleme kullanılmıştır. Ölçüt örnekleme yöntemindeki temel anlayış, önceden belirlenmiş bir dizi ölçütü karşılayan bütün durumların çalışılmasıdır (Yıldırım ve Şimşek, 2008). Bu araştırmaya katılan çalışma grubunun seçiminde, öğrencilerin 4. 5. 6. ve 7. sınıfta okuyor olması ve fen ve teknoloji dersini başarı ile geçmiş olmaları temel ölçüt olarak belirlenmiştir.

\section{Çalışma Grubu}

Araştırma, Kırşehir Merkez'de bulunan 2 ilköğretim okulunun, 2011-2012 eğitim-öğretim yılı itibariyle 4. 5. 6. ve 7. sınıflarına devam eden toplam 300 kişilik ilköğretim öğrencisiyle gerçekleştirilmiştir. Öğrencilerin cinsiyetlerine göre dağılımları Tablo 1'de verilmiştir.

Tablo 1. Öğrencilerin Cinsiyetlerine Göre Dağılımı

\begin{tabular}{lcc}
\hline Cinsiyet & f & \% \\
\hline Kiz & 134 & 44.7 \\
Erkek & 166 & 55.3 \\
Toplam & 300 & 100.0 \\
\hline
\end{tabular}

Öğrencilerin cinsiyete göre dağılımlarına bakıldığında 134’ü kız, 166's1 erkektir. Öğrencilerin \% 44.7'sini kızlar, \% 55.3'ünü erkekler oluşturmuştur. Öğrencilerin sınıflara göre dağılımı Tablo 2'de verilmiştir.

Tablo 2. Öğrencilerin Sınıflara Göre Dağılımı

\begin{tabular}{lll}
\hline Siniflar & f & $\%$ \\
\hline
\end{tabular}




\begin{tabular}{lcc}
\hline 4. Sinif & 71 & 23.7 \\
5. Sinif & 78 & 26.0 \\
6. Sinif & 73 & 24.3 \\
7. Sinif & 78 & 26.0 \\
Toplam & 300 & 100.0 \\
\hline
\end{tabular}

Öğrencilerin sınıflara göre dağılımına bakıldığında 71'inin 4. s1nıf, 78'inin 5. sınıf, 73'ünün 6. sınıf ve 78'inin 7. sınıf olduğu görülmektedir. Dağılımın \% 23.7'sini 4. sınıf, \% 26.0'ını 5. sınıf, \% 24.3'ünü 6. sınıf, \% 26.0'1nı 7. sınıf oluşturmaktadır.

\section{Veri Toplama Süreci}

Öğrencilerin soyut işlem döneminde kazanması beklenen davranışları ölçmek için, bir ölçme aracı geliştirilmek istenmiştir. Bu bakımdan her bir beceri için (hipotetik düşünme, olasılıklı düşünme, kombinezonlu düşünme, korelasyonel düşünme, oranlı düşünme, değişkenleri belirleme ve tanımlama) sorular hazırlanarak taslak form oluşturulmuştur. Taslak form, kapsam geçerliğinin belirlenmesi amacıyla fen eğitimi alanlarında uzman akademisyenlerin görüşüne sunulmuştur. Uzmanların geri bildirimleri doğrultusunda gerekli düzenlemelerin yapılmasının ardından 12 sorudan oluşan bir yapıda uygulamaya hazır hale getirilmiştir. Hazırlanan ölçme aracı "Soyut İşlemler Dönemi Beceri Testi (SİDBT)” olarak isimlendirilmiştir. Ölçme aracında 2 tane yapılandırılmış, 10 tane yarı yapılandırılmış biçimde soru yer almaktadır (EK:1).

Her bir soru için alan eğitimi uzmanlarının görüşlerine başvurulmuştur. Hazırlanan soruların ilgili işlem becerisinde yer alıp almadığı ve maddelerin güvenirlik hesabı için Miles ve Huberman'ın, Gü- 
venirlik=Görüş Birliği / Görüş Birliği + Görüş Ayrllı̆̆ formülünden yararlanılmıştır (akt; Afacan, 2011). Güvenirlik=11/ $11+1, \% 92$ olarak hesaplanmıştır.

\section{Verilerin Analizi}

Verilerin çözümlenmesinde, öğrencilerin sorulara verdikleri doğru cevaplar için 1 , boş bırakılan ve yanlış verilen her bir cevap için 0 kodlaması yapılarak veri girişi gerçekleştirilmiştir. Her bir soru için öğrencilerden alınan doğru ve yanlış cevapların sınıf seviyelerine göre frekans ve yüzdeleri oluşturulmuştur. Öğrencilerin vermiş olduğu cevaplar yorumlanmıştır.

\section{Bulgular ve Yorum}

$\mathrm{Bu}$ bölümde araştırmada elde edilen bulgulara ve bulguların yorumlarına yer verilmiştir.

\section{Hipotetik Düşünme Becerisinin Gelişimine İlişkin Bulgular}

Bir problemi çözmek için oluşturulan geçici çözüm yolu niteliğindeki bilgilere hipotez denir. Günlük hayatta veya eğitim öğretimde karşılaşılan bir sorunun çözmek için olası çözüm yolları geliştirip, bunları belirli bir düzene göre yapmayı sağlayan düşünme sürecidir (Özmen, Çepni Ed., 2011).

Geliştirilen Soyut İşlemler Dönemi Beceri Testinde, hipotetik düşünme becerisini ölçücü 4 soruya yer verilmiştir. Sorulardan 2 tanesi araştırma sorusu oluşturmaya, diğer 2'si ise hipotez kurmaya yöneliktir. 
a) Araştırma sorusu oluşturma ile ilgili her bir soruya doğru ve yanlış cevap veren öğrencilerin sınıflarına göre sayıları ve yüzdelik dağılımları Tablo 3'te verilmiştir.

Tablo 3. Araştırma Sorularına Verilen Doğru ve Yanlış Cevapların Sınıf Seviyelerine Göre Dağılımı

\begin{tabular}{|c|c|c|c|c|c|c|c|c|}
\hline \multirow{5}{*}{ SINIFLAR } & \multicolumn{8}{|c|}{ HİPOTETİK DÜŞÜNME } \\
\hline & \multicolumn{8}{|c|}{ Araştırma Sorusu Oluşturma } \\
\hline & \multicolumn{4}{|c|}{ 1.soru } & \multicolumn{4}{|c|}{ 2.soru } \\
\hline & \multicolumn{2}{|c|}{ Doğru } & \multicolumn{2}{|c|}{ Yanlış } & \multicolumn{2}{|c|}{ Doğru } & \multicolumn{2}{|c|}{ Yanlış } \\
\hline & $\mathrm{f}$ & $\%$ & $f$ & $\%$ & $\mathrm{f}$ & $\%$ & $\mathrm{f}$ & $\%$ \\
\hline 4.Sinif & 0 & 0 & 71 & 100.0 & 0 & 0 & 71 & 100.0 \\
\hline 5.Sinif & 11 & 14.1 & 67 & 85.9 & 6 & 7.7 & 72 & 92.3 \\
\hline 6.Sinif & 19 & 26.0 & 54 & 74.0 & 9 & 12.3 & 64 & 87.7 \\
\hline 7.Sinif & 36 & 46.2 & 42 & 53.8 & 29 & 37.2 & 49 & 62.8 \\
\hline TOPLAM & 66 & 22.0 & 234 & 78.0 & 44 & 14.7 & 256 & 85.3 \\
\hline
\end{tabular}

Tablo 3 incelendiğinde araştırma sorusu oluşturmaya ilişkin 1. soruya 4. sınıf öğrencilerinin doğru cevap veremediği, sorunun 5. sınıf öğrencilerinin \% 14.1'i, 6. sinıf öğrencilerinin \% 26's1 ve 7. sinıf öğrencilerinin \% 46.2'si tarafından doğru olarak yanıtlandığı görülmüştür. Diğer soruyu ise 4. sınıf öğrencileri yine cevaplandıramazken, 5. sinıf öğrencileri \% 7.7, 6. sinıf öğrencileri \% 12.3, 7. sinıf öğrencileri \% 37.2'lik bir oranla doğru cevaplamıştır. Sınıf seviyeleri artıkça sorulara doğru yanıt veren öğrencilerin sayıları artmaktadır. Genel bir değerlendirme yapıldığında 1. soru öğrencilerin \% 22'si, 2. soru ise \% 14.7'si tarafından doğru olarak cevaplandırılmıştır. 
Aşağıda araştırma sorusu oluşturmaya yönelik sorulan sorulardan birine ve öğrencilerin soruya verdikleri cevaplardan birkaçına yer verilmiştir.

Soru: Farklı yüzeylerde bulunan cisimler ve onlara uygulanan kuvvetlerle ilgili görsele ilişkin Bulut yukarıdaki düzenekleri hazırlayarak sürtünme kuvveti ile yüzeyin cinsi arasındaki ilişkiyi incelemek istemiştir. Buna göre Bulut'un araştırma sorusu ne olmalıdır?

Sorusuna $\ddot{\mathbf{O}}_{123}$ sürtünme kuvvetinin etkisi, $\ddot{\mathbf{O}}_{113}$ zemin ve onun kilosu onu etkiler mi?, Ö$_{1}$ en güçlüsü hangisi?, Ö$_{296}$ hangi zeminde sürtünme olur?, $\ddot{\boldsymbol{O}}_{72}$ ağırlıklarl ve zeminleri farklı olan cisimlerden hangisi daha hızlı gider?, $\mathbf{O}_{\mathbf{2 4 8}}$ sürtünme kuvveti ile yüzeyin cinsi arasında nasıl bir ilişki vardır?, Ö$_{250}$ sürtünme kuvveti yüzeyin cinsine bağll mıdır?, $\ddot{\mathbf{O}}_{243}$ sürtünme kuvveti ile yüzeyin cinsi arasında ilişki var mıdır? cevaplarını vermişlerdir.

b) Hipotez kurma ile ilgili her bir soruya doğru ve yanlış cevap veren öğrencilerin sınıflarına göre sayıları ve yüzdelik dağılımları Tablo 4'te verilmiştir.

Tablo 4. Hipotez Kurma Sorularına Verilen Doğru ve Yanlış Cevapların Sınıf Seviyelerine Göre Dağılımı

\begin{tabular}{|c|c|c|c|c|c|c|c|c|}
\hline \multirow{5}{*}{ SINIFLAR } & \multicolumn{8}{|c|}{ HIIPOTETİK DÜŞÜNME } \\
\hline & \multicolumn{8}{|c|}{ Hipotez Kurma } \\
\hline & \multicolumn{4}{|c|}{ 1.soru } & \multicolumn{4}{|c|}{ 2.soru } \\
\hline & \multicolumn{2}{|c|}{ Doğru } & \multicolumn{2}{|c|}{ Yanlış } & \multicolumn{2}{|c|}{ Doğru } & \multicolumn{2}{|c|}{ Yanlış } \\
\hline & $\mathrm{f}$ & $\%$ & $f$ & $\%$ & $\mathrm{f}$ & $\%$ & $\mathrm{f}$ & $\%$ \\
\hline 4. Sinıf & 0 & 0 & 71 & 100.0 & 0 & 0 & 71 & 100.0 \\
\hline
\end{tabular}




\begin{tabular}{ccccccccc}
\hline 5. Sinif & 7 & 9.0 & 71 & 91.0 & 2 & 2.6 & 76 & 97.4 \\
& & & & & & & & \\
\hline 6. Sinıf & 13 & 17.8 & 60 & 82.2 & 6 & 8.2 & 67 & 91.8 \\
& & & & & & & & \\
\hline 7. Sinıf & 27 & 34.6 & 51 & 65.4 & 20 & 25.6 & 58 & 74.4 \\
\hline TOPLAM & 47 & 15.7 & 253 & 84.3 & 28 & 9.3 & 272 & 90.7
\end{tabular}

Tablo 4 incelendiğinde hipotez kurma ile ilgili 1. sorunun 4. sınıf öğrencileri tarafından yanıtlanamadığı, sorunun 5. sınıf öğrencilerinin \% 9'u, 6. sinıf öğrencilerinin \% 17.8'i ve 7. sınıf öğrencilerinin \% 34.6's1 tarafından doğru cevaplandırıldığ1 görülmektedir. 2. soru ise yine 4. sınıf öğrencileri tarafindan cevaplandırılamazken, 5. sınıf öğrencilerinin \% 2.6's1, 6. sınıf öğrencilerinin \% 8.2'si, 7. sınıf öğrencilerinin ise \% 25.6'sı tarafından doğru olarak yanıtlanmıştır. Sınıf seviyeleri arttıkça sorulara doğru yanıt veren öğrencilerin sayılarında da artış gözlenmektedir. Genel bir değerlendirme yapıldığında ise 1. soru öğrencilerin \% 15.7'si 2. soru ise \% 9.3'ü tarafindan doğru olarak cevaplandirılmıştır.

Aşağıda hipotez kurmaya yönelik sorulan sorulardan birine ve öğrencilerin soruya verdikleri cevaplardan birkaçına yer verilmiştir.

Soru: Pamuk, tohum ve farklı ortam şartlarından oluşan dört ayrı düzeneğe ilişkin, Ahmet çimlenme için gerekli olan şartları araştırmak istemiş ve düzenekleri hazırlamıştır. Ahmet'in amacına ulaşabilmesi için geliştireceği hipotezlerden biri ne olabilir?

Sorusuna $\ddot{\mathbf{O}}_{\mathbf{1 3 5}}$ çimlenebilir, $\ddot{\mathbf{O}}_{\mathbf{2 7 4}}$ tohum yetişir mi? $\ddot{\mathbf{O}}_{\mathbf{8 8}}$ islak pamuk ve karanlık, $\ddot{\mathbf{O}}_{104}$ uygun slcaklık ve gerekli olan lşık verilmesi 
gerekir, $\ddot{\mathbf{O}}_{\mathbf{1 8 1}}$ çimlenme için ışık gereklidir, $\mathbf{O}_{\mathbf{2 0 8}}$ sıcaklık çimlenmeye etki eder, $\ddot{\mathbf{O}}_{209}$ nem çimlenme için gereklidir, $\ddot{\mathbf{O}}_{169}$ lşı̆̆ın çimlenmeye etkisi yoktur. cevaplarını vermişlerdir.

\section{Değişkenleri Belirleme ve Tanımlama Becerisinin Gelişimine İliş-} kin Bulgular

Gözlenen bir olayı etkileyecek faktörlere değişken adı verilir. $\mathrm{Bu}$ süreç hipotez olay ya da kavramın test edilmesinde durumun sürekliliğini etkileyen bağımlı ve bağımsız etkenlerin belirlemesi, tanımlanması ve kontrol altına alınmasını içerir (Özmen, Çepni Ed., 2011).

Testte değişkenleri belirleme ve tanımlama becerisine yönelik 6 soru bulunmaktadır. Sorulardan 2 tanesi bağımlı değişkeni, 2 tanesi bağımsız değişkeni ve diğer 2'si ise kontrol edilen değişkeni bulmaya yöneliktir.

a) Bağımlı değişkeni belirleme ile ilgili her bir soruya doğru ve yanlış cevap veren öğrencilerin sınıflarına göre sayıları ve yüzdelik dağılımları Tablo 5'te verilmiştir.

Tablo 5. Bağımlı Değişkeni Belirleme Sorularına Verilen Doğru ve Yanlış Cevapların Sınıf Seviyelerine Göre Dağılımı

\begin{tabular}{|c|c|c|c|c|c|c|c|c|}
\hline \multirow{5}{*}{ SINIFLAR } & \multicolumn{8}{|c|}{ DEĞİŞKENLERİ BELİRLEME ve TANIMLAMA } \\
\hline & \multicolumn{8}{|c|}{ Bağımlı Değişken } \\
\hline & \multicolumn{4}{|c|}{ 1.soru } & \multicolumn{4}{|c|}{ 2.soru } \\
\hline & \multicolumn{2}{|c|}{ Doğru } & \multicolumn{2}{|c|}{ Yanlıș } & \multicolumn{2}{|c|}{ Doğru } & \multicolumn{2}{|c|}{ Yanlış } \\
\hline & $\mathrm{f}$ & $\%$ & $\mathrm{f}$ & $\%$ & $\mathrm{f}$ & $\%$ & $\mathrm{f}$ & $\%$ \\
\hline 4. Sinif & 0 & 0 & 71 & 100.0 & 0 & 0 & 71 & 100.0 \\
\hline 5. Sinif & 16 & 20.5 & 62 & 79.5 & 11 & 14.1 & 67 & 85.9 \\
\hline
\end{tabular}




\begin{tabular}{ccccccccc}
\hline 6. Sinıf & 12 & 16.4 & 61 & 83.6 & 6 & 8.2 & 67 & 91.8 \\
\hline 7. Sınıf & 35 & 44.9 & 43 & 55.1 & 26 & 33.3 & 52 & 66.7 \\
& & & & & & & & \\
\hline TOPLAM & 63 & 21.0 & 237 & 79.0 & 43 & 14.3 & 257 & 85.7 \\
\hline
\end{tabular}

Tablo 5 incelendiğinde bağımlı değişkeni belirlemeye yönelik 1 . sorunun 4. sınıf öğrencileri tarafından cevaplandırılamadığı, 5. sınıf öğrencilerinin \% 20.5'i, 6. sinıf öğrencilerinin \% 16.4'ü, 7. sinıf öğrencilerinin \% 44.9'u tarafından doğru yanıtlandığı görülmektedir. Diğer soru ise yine 4. sınıf öğrencileri tarafından cevaplandırılamazken, 5. sınıf öğrencilerinin \% 14.1'i, 6. sinıf öğrencilerinin \% 8.2'si ve 7. sınıf öğrencilerinin \% 33.3'ü tarafından doğru yanıtlandırılmıştır. 5. sınıf öğrencilerinin bağımlı değişkeni belirlemede 6. sınıf öğrencilerinden daha başarılı olması dikkat çekicidir. Genel olarak değerlendirildiğinde 1. soru öğrencilerin \% 21'i, 2.soru ise \% 14.3’ü tarafından doğru olarak cevaplandırılmıştır.

Aşağıda bağımlı değişkeni belirlemeye yönelik sorulan sorulardan birine ve öğrencilerin soruya verdikleri cevaplardan birkaçına yer verilmiştir.

Soru: Özdeş ampul pil ve kabloların kullanıldığı, test uçlarına demir ve bakır tellerin takılarak farklı parlaklıkların elde edildiği 2 elektrik düzeneğini içeren görsele ilişkin, Emre düzenekleri kurarak ampul parlaklığını gözlemlemiştir. Emre'nin deneyindeki bağımlı değişkeni belirleyiniz.

Sorusuna $\ddot{\mathbf{O}}_{6}$ demir elektriği çekiyor, $\ddot{\mathbf{O}}_{189}$ pil sayısı, $\ddot{\mathbf{O}}_{67}$ pil ampul 
ve kablo, $\ddot{\mathbf{O}}_{\mathbf{1 9 6}}$ ampul, Ö$_{66}$ baklr ve demir tel, $\ddot{\boldsymbol{O}}_{82}$ pil ve ampul saylst, $\ddot{\mathbf{O}}_{295}$ iletkenin cinsi, $\ddot{\mathbf{O}}_{104}$ ampul parlakliğl, cevaplarını vermişlerdir.

b) Bağımsız değişkeni belirleme ile ilgili her bir soruya doğru ve yanlış cevap veren öğrencilerin sınıflarına göre sayıları ve yüzdelik dağılımları Tablo 6'da verilmiştir

Tablo 6. Bağımsız Değişkeni Belirleme Sorularına Verilen Doğru ve Yanlış Cevapların Sınıf Seviyelerine Göre Dağılımı

\begin{tabular}{|c|c|c|c|c|c|c|c|c|}
\hline \multirow{5}{*}{ SINIFLAR } & \multicolumn{8}{|c|}{ DEĞİŞKENLERİ BELİRLEME ve TANIMLAMA } \\
\hline & \multicolumn{8}{|c|}{ Bağımsız Değişken } \\
\hline & \multicolumn{4}{|c|}{ 1.soru } & \multicolumn{4}{|c|}{ 2.soru } \\
\hline & \multicolumn{2}{|c|}{ Doğru } & \multicolumn{2}{|c|}{ Yanlış } & \multicolumn{2}{|c|}{ Doğru } & \multicolumn{2}{|c|}{ Yanlış } \\
\hline & $\mathrm{f}$ & $\%$ & $\mathrm{f}$ & $\%$ & $\mathrm{f}$ & $\%$ & $\mathrm{f}$ & $\%$ \\
\hline 4. Sinif & 0 & 0 & 71 & 100.0 & 0 & 0 & 71 & 100.0 \\
\hline 5. Sinif & 17 & 21.8 & 61 & 78.2 & 13 & 16.7 & 65 & 83.3 \\
\hline 6. Sinif & 7 & 9.6 & 66 & 90.4 & 5 & 6.8 & 68 & 93.2 \\
\hline 7. Sinif & 42 & 53.8 & 36 & 46.2 & 31 & 39.7 & 47 & 60.3 \\
\hline TOPLAM & 66 & 22.0 & 234 & 78.0 & 49 & 16.3 & 251 & 83.7 \\
\hline
\end{tabular}

Tablo 6 incelendiğinde bağımsız değişkeni belirlemeye yönelik1. Sorunun 4. sınıf öğrencileri tarafindan cevaplandırılamadığı, 5. sınıf öğrencilerinin \% 21.8'i, 6. sınıf öğrencilerinin \% 9.6's1, 7. sınıf öğrencilerinin \% 53.8'i tarafından doğru olarak yanıtlandığı görülmektedir. Diğer soru ise yine 4. sınıf öğrencileri tarafından cevaplandırılamazken, 5. sınıf öğrencilerinin \% 16.7'si, 6. sınıf öğrencilerinin \% 6.8'i ve 7. sınıf öğrencilerinin \% 39.7'si tarafından doğru olarak yanıtlanmıştır. Genel olarak değerlendirildiğinde 1. soru öğrencilerin \% 22'si 2. soru ise \% 16.3'ü tarafından doğru olarak cevaplandırılmıştır. 
Aşağıda bağımlı değişkeni belirlemeye yönelik sorulan sorulardan birine ve öğrencilerin soruya verdikleri cevaplardan birkaçına yer verilmiştir.

Soru: Özdeş ampul pil ve kabloların kullanıldığı, test uçlarına demir ve bakır tellerin takılarak farklı parlaklıkların elde edildiği 2 elektrik düzeneğini içeren görsele ilişkin, Emre düzenekleri kurarak ampul parlaklığını gözlemlemiştir. Emre'nin deneyindeki bağımsız değişkeni belirleyiniz.

Sorusuna $\ddot{\mathbf{O}}_{104}$ ampul saylsl, $\ddot{\mathbf{O}}_{297}$ ampul parlaklığl, $\ddot{\mathbf{O}}_{\mathbf{1 2 1}}$ pil sayl$s l, \ddot{\mathbf{O}}_{139}$ demir tel, $\ddot{\mathbf{O}}_{\mathbf{2 8 6}}$ lamba, $\ddot{\mathbf{O}}_{\mathbf{2 5 8}}$ ampul, pil, $\ddot{\mathbf{O}}_{\mathbf{2 8 2}}$ telin cinsi, $\ddot{\mathbf{O}}_{219}$ kullanılan teller, cevaplarını vermişlerdir.

c) Kontrol edilen değişkeni belirleme ile ilgili her bir soruya doğru ve yanlış cevap veren öğrencilerin sınıflarına göre sayıları ve yüzdelik dağılımları Tablo 7'de verilmiştir.

Tablo 7. Kontrol Edilen Değişkeni Belirleme Sorularına Verilen Doğru ve Yanlış Cevapların Sınıf Seviyelerine Göre Dağılımı

\begin{tabular}{|c|c|c|c|c|c|c|c|c|}
\hline \multirow{4}{*}{ SINIFLAR } & \multicolumn{8}{|c|}{ DEĞİŞKENLERİ BELİRLEME ve TANIMLAMA } \\
\hline & \multicolumn{4}{|c|}{ 1.soru } & \multicolumn{4}{|c|}{ 2.soru } \\
\hline & \multicolumn{2}{|c|}{ Doğru } & \multicolumn{2}{|c|}{ Yanlış } & \multicolumn{2}{|c|}{ Doğru } & \multicolumn{2}{|c|}{ Yanlış } \\
\hline & $f$ & $\%$ & $f$ & $\%$ & $\mathrm{f}$ & $\%$ & $\mathrm{f}$ & $\%$ \\
\hline 4. Sinif & 0 & 0 & 71 & 100.0 & 0 & 0 & 71 & 100.0 \\
\hline 5. Sinıf & 21 & 26.9 & 57 & 73.1 & 12 & 15.4 & 66 & 84.6 \\
\hline 6. Sinif & 4 & 5.5 & 69 & 94.5 & 2 & 2.7 & 71 & 97.3 \\
\hline 7. Sinif & 32 & 41.0 & 46 & 59.0 & 22 & 28.2 & 56 & 71.8 \\
\hline TOPLAM & 57 & 19.0 & 243 & 81.0 & 36 & 12.0 & 264 & 88.0 \\
\hline
\end{tabular}


Tablo 7 incelendiğinde kontrol edilen değişkeni belirlemeye yönelik 1. soruyu 4. sınıf öğrencileri cevaplandıramazken, soru 5. sınıf öğrencilerinin \% 26.9'u, 6. sınıf öğrencilerinin \% 5.5'i, 7. sınıf öğrencilerinin \% 41'i tarafından doğru olarak cevaplandırılmıştır. Diğer sorunun ise yine 4. sınıf öğrencileri tarafından cevaplandırılamadığı, 5 . sınıf öğrencilerinin \% 15.4'ü, 6. sınıf öğrencilerinin 2.7'si ve 7. sinıf öğrencilerinin \% 28.2'si tarafından doğru olarak yanıtlandığı görülmüştür. Genel olarak değerlendirildiğinde 1. soru öğrencilerin \% 19'u, 2. soru ise \% 12'si tarafından doğru olarak cevaplandırılmıştır.

Aşağıda kontrol edilen değişkeni belirlemeye yönelik sorulan sorulardan birine ve öğrencilerin soruya verdikleri cevaplardan birkaçına yer verilmiştir.

Soru: Özdeş ampul pil ve kabloların kullanıldığı, test uçlarına demir ve bakır tellerin takılarak farklı parlaklıkların elde edildiği 2 elektrik düzeneğini içeren görsele ilişkin, Emre düzenekleri kurarak ampul parlaklığını gözlemlemiştir. Emre'nin deneyindeki kontrol edilen değişkeni belirleyiniz.

Sorusuna $\ddot{\mathbf{O}}_{66}$ ampul parlaklı̆̆,$\ddot{\mathbf{O}}_{\mathbf{1 3 9}}$ baklr tel, $\ddot{\mathbf{O}}_{\mathbf{2 6 5}}$ pil sayısl, $\ddot{\mathbf{O}}_{\mathbf{7 8}}$ demir tel, $\ddot{\mathbf{O}}_{\mathbf{1 8 1}}$ iletken tel, $\ddot{\mathbf{O}}_{\mathbf{1 6 3}}$ tel cinsi, Ö$_{\mathbf{2 0 9}}$ kablo pil ve ampul saylst, cevaplarını vermişlerdir.

\section{Olasılıklı Düşünme Becerisinin Gelişimine İlişkin Bulgular}


Bir olayın veya hipotezin başlangıcından sonu evresine kadar olan bütün aşamalarda mümkün olan her türlü olasılıkları düşünebilme yeteneğidir (Özmen, Çepni Ed., 2011).

Testte olasılıklı düşünme becerisini ölçmeye yönelik 2 soruya yer verilmiştir. Olasılıklı düşünme ile ilgili her bir soruya doğru ve yanlış cevap veren öğrencilerin sınıflarına göre sayıları ve yüzdelik dağılımları Tablo 8'de verilmiştir.

Tablo 8. Olasılıklı Düşünme Sorularına Verilen Doğru ve Yanlış Cevapların Sınıf Seviyelerine Göre Dağılımı

\begin{tabular}{|c|c|c|c|c|c|c|c|c|}
\hline \multicolumn{9}{|c|}{ OLASILIKLI DÜŞÜNME } \\
\hline \multirow{3}{*}{ SINIFLAR } & \multicolumn{4}{|c|}{ 1.soru } & \multicolumn{4}{|c|}{ 2.soru } \\
\hline & \multicolumn{2}{|c|}{ Doğru } & \multicolumn{2}{|c|}{ Yanlış } & \multicolumn{2}{|c|}{ Doğru } & \multicolumn{2}{|c|}{ Yanlış } \\
\hline & $F$ & $\%$ & $\mathrm{f}$ & $\%$ & $\mathrm{f}$ & $\%$ & $\mathrm{f}$ & $\%$ \\
\hline 4. Sinif & 16 & 22.5 & 55 & 77.5 & 1 & 1.4 & 70 & 98.6 \\
\hline 5. Sinif & 37 & 47.4 & 41 & 52.6 & 36 & 46.2 & 42 & 53.8 \\
\hline 6. Sinif & 54 & 74.0 & 19 & 26.0 & 15 & 20.5 & 58 & 79.5 \\
\hline 7. Sinif & 67 & 85.9 & 11 & 14.1 & 41 & 52.6 & 37 & 47.4 \\
\hline TOPLAM & 174 & 58.0 & 126 & 42.0 & 93 & 31.0 & 207 & 69.0 \\
\hline
\end{tabular}

Tablo 8 incelendiğinde araştırma sorusu oluşturmaya ilişkin 1. soruya 4. sınıf öğrencilerin \% 22.5'i, 5. sinıf öğrencilerinin \% 47.4'ü, 6. sinıf öğrencilerinin \% 74'ü ve 7. sinıf öğrencilerinin \% 46.2'si tarafından doğru olarak yanıtlandığı görülmüştür. Diğer soruyu ise 4. sınıf öğrencileri \%1.4, 5. sınıf öğrencileri \% 46.2, 6. sınıf öğrencileri \% 20.5, 7. sınıf öğrencileri \% 52.6'lık bir oranla doğru cevaplamıştır. Genel 
değerlendirme yapıldığında 1. soru öğrencilerin \% 58 'i, $\quad$ 2. soru ise $\%$ 31 'i tarafından doğru olarak cevaplandırıldığı görülmektedir.

Aşağıda olasılıklı düşünmeye yönelik sorulan sorulardan birine ve öğrencilerin soruya verdikleri cevaplardan birkaçına yer verilmiştir.

Soru: Zeynep kutuplarını bilmediği K L ve M mıknatıslarını şekildeki gibi birbirine yaklaştırdığında $\mathrm{K}$ ve L'nin birbirini ittiğini, K ve M'nin ise çektiğini görüyor. Buna göre $\mathrm{M}$ ve L mıknatıslarını birbirine yaklaştırdığında etkileşimleri nasıl olur? Açıklayınız.

Sorusuna $\ddot{\mathbf{O}}_{76}$ iter, aynı kutuplar yan yana gelir, $\ddot{\mathbf{O}}_{\mathbf{1 3 8}}$ birbirini iter çünkü kutupları farkl, $\mathbf{O}_{\mathbf{1 8 3}}$ çekerler çünkü ikisi de zıt, Ö$_{\mathbf{1 2 9}}$ bence çeker, $\mathbf{O ̈}_{\mathbf{2 4 1}}$ birbirini çeker çünkü zıt kuvvetler, cevaplarını vermişlerdir.

\section{Kombinezonlu Düşünme Becerisinin Gelişimine İlişkin Bulgular}

Tanımlanmamış olsa bile olası bütün teorik veya deneysel ilişkileri sistematik bir şekilde göz önüne alan zihinsel beceridir. Bu beceri bir olayın, bir deneyin veya kuramsal bir modelin mümkün olabilecek tüm yönlerinin düşünülmesi şeklinde gerçekleşir (Özmen, Çepni Ed., 2011).

Testte kombinezonlu düşünme becerisini ölçmeye yönelik 2 soruya yer verilmiştir. Kombinezonlu düşünme ile ilgili her bir soruya doğru ve yanlış cevap veren öğrencilerin sınıflarına göre sayıları ve yüzdelik dağılımları Tablo 9'da verilmiştir.

Tablo 9. Kombinezonlu Düşünme Sorularına Verilen Doğru ve Yanlış Cevapların Sınıf Seviyelerine Göre Dağılımı 


\begin{tabular}{ccccccccc}
\hline & \multicolumn{9}{c}{ KOMBİNEZONLU DÜŞÜNME } \\
\hline \multirow{3}{*}{ SINIFLAR } & \multicolumn{3}{c}{ 1.soru } & \multicolumn{5}{c}{ 2.soru } \\
\cline { 2 - 10 } & \multicolumn{2}{c}{ Doğru } & \multicolumn{2}{c}{ Yanlış } & \multicolumn{2}{c}{ Doğru } & \multicolumn{2}{c}{ Yanlış } \\
\cline { 2 - 10 } & f & $\%$ & f & $\%$ & f & $\%$ & f & $\%$ \\
\hline 4. Sinıf & 25 & 35.2 & 46 & 64.8 & 28 & 39.4 & 43 & 60.6 \\
5. Sinıf & 51 & 65.4 & 27 & 34.6 & 57 & 73.1 & 21 & 26.9 \\
6. Sinıf & 46 & 63.0 & 27 & 37.0 & 49 & 67.1 & 24 & 32.9 \\
7. Sinıf & 64 & 82.1 & 14 & 17.9 & 66 & 84.6 & 12 & 15.4 \\
TOPLAM & 186 & 62.0 & 114 & 38.0 & 200 & 66.7 & 100 & 33.3 \\
\hline
\end{tabular}

Tablo 9 incelendiğinde korelasyonel düşünme ile ilgili 1. sorunun 4. sınıf öğrencilerinin \% 35.2'si, 5. sınıf öğrencilerinin \% 65.4'ü, 6 . sınıf öğrencilerinin \% 63'ü ve 7. sınıf öğrencilerinin \% 82.1'i tarafından doğru olarak cevaplandırılmıştır. 2. sorunun ise 4. sınıf öğrencilerinin \% 39.4'ü, 5. sınıf öğrencilerinin \% 73.1'i, 6. sınıf öğrencilerinin \% 67.1'i, 7. sınıf öğrencilerinin ise \% 84'ü tarafından doğru olarak cevaplandırıldığı görülmüştür. Genel olarak değerlendirildiğinde 1. soru öğrencilerin \% 62'si, 2. soru ise \% 66.7'si tarafından doğru olarak cevaplandırılmıştır.

Aşağıda olasılıklı düşünmeye yönelik sorulan sorulardan birine ve öğrencilerin soruya verdikleri cevaplardan birkaçına yer verilmiştir.

Soru: Farklı ampul ve pil sayılarından oluşan düzeneklere ilişkin, Merve, Fen ve Teknoloji dersinde performans görevi için bir gece lambası tasarlayacaktır. Gece lambasının çok 1şık vermesini isteyen Merve, yukarıdaki düzeneklerden hangisini kullanmalıdır? (Ampul, pil ve kablolar özdeştir.)

Sorusuna $\ddot{\mathbf{O}}_{\mathbf{1 2 2}}$ III seçmelidir bence, Ö$_{45}$ II'yi kullanmalıdır çok ampul olduğu için, Ö$_{\mathbf{5 3}}$ büyük lamba, Ö$_{\mathbf{1 1 1}}$ V. düzeneği çünkü çok pil var çok enerji verir, cevaplarını vermişlerdir. 


\section{Korelasyonel Düşünme Becerisinin Gelişimine İlişkin Bulgular}

Değişen bir nesnenin bir başka değişken nesne ile ilişkilendirilmesidir Araştırılan olay veya durumlar arasında ne tür ilişkilerin, bağlantıların olduğunun veya olmadığının düşünülmesi şeklinde yürüyen süreçtir (Özmen, Çepni Ed., 2011).

Testte korelasyonel düşünme becerisini ölçmeye yönelik 2 soruya yer verilmiştir. Korelasyonel düşünme ile ilgili her bir soruya doğru ve yanlış cevap veren öğrencilerin sınıflarına göre sayıları ve yüzdelik dağılımları Tablo 10'da verilmiştir.

Tablo 10. Korelasyonel Düşünme Sorularına Verilen Doğru ve Yanlış Cevapların Sınıf Seviyelerine Göre Dağılımı

\begin{tabular}{|c|c|c|c|c|c|c|c|c|}
\hline \multirow{4}{*}{ SINIFLAR } & \multicolumn{8}{|c|}{ KORELASYONEL DÜŞÜNME } \\
\hline & \multicolumn{4}{|c|}{ 1.soru } & \multicolumn{4}{|c|}{2. soru } \\
\hline & \multicolumn{2}{|c|}{ Doğru } & \multicolumn{2}{|c|}{ Yanlış } & \multicolumn{2}{|c|}{ Doğru } & \multicolumn{2}{|c|}{ Yanlıș } \\
\hline & $\mathrm{f}$ & $\%$ & $\mathrm{f}$ & $\%$ & $\mathrm{f}$ & $\%$ & $\mathrm{f}$ & $\%$ \\
\hline 4. Sinif & 6 & 8.5 & 65 & 91.5 & 18 & 25.4 & 53 & 74.6 \\
\hline 5. Sinif & 34 & 43.6 & 44 & 56.4 & 20 & 25.6 & 58 & 74.4 \\
\hline 6. Sinif & 20 & 27.4 & 53 & 726 & 20 & 27.4 & 53 & 72.6 \\
\hline 7. Sinif & 54 & 69.2 & 24 & 30.8 & 51 & 65.4 & 27 & 34.6 \\
\hline TOPLAM & 114 & 38.0 & 186 & 62.0 & 109 & 36.3 & 191 & 63.7 \\
\hline
\end{tabular}

Tablo 10 incelendiğinde korelasyonel düşünme ile ilgili 1. sorunun 4. sınıf öğrencilerinin \% 8.5'i, 5. sınıf öğrencilerinin \% 43.6's1, 6. sınıf öğrencilerinin \% 27.4'ü ve 7. sınıf öğrencilerinin \% 69.2'si tarafından doğru olarak cevaplandırılmıştır. 2. sorunun ise 4. sınıf öğrencilerinin \% 25.4'ü, 5. sınıf öğrencilerinin \% 25.6's1, 6. sınıf öğrencilerinin \% 27.4'ü 7. sınıf öğrencilerinin ise \% 65.4'ü doğru olarak 
cevaplandırıldığı görülmüştür. Genel olarak değerlendirildiğinde 1. soru öğrencilerin \% 38'i, 2. soru ise \% 36.3'ü tarafindan doğru olarak cevaplandırılmıştır.

Aşağıda korelasyonel düşünmeye yönelik sorulan sorulardan birine ve öğrencilerin soruya verdikleri cevaplardan birkaçına yer verilmiştir.

Soru: İlk sıcaklıkları aynı farklı miktarlardaki suların özdeş ısıtıcılarla 1sıtılarak belirli zaman aralıklarında ulaştıkları sıcaklıkların verildiği resim ve tablo ile ilgili bilgilere göre su miktarları ile sıcaklık değişimi arasında nasıl bir ilişki vardır?

Sorusuna $\ddot{\mathbf{O}}_{\mathbf{1 6 5}}$ su miktarl ne kadar fazla ise sicaklık o kadar az fazlalaşır, $\ddot{\mathbf{O}}_{163}$ slcaklık çok olursa su buharlaşır, $\ddot{\mathbf{O}}_{141}$ ateşin altında sicaklık artar, $\ddot{\mathbf{O}}_{205}$ su oranı arttıkça sıcaklık artar, $\ddot{\mathbf{O}}_{\mathbf{8 9}}$ su ve sicaklık farklı olabiliyor, $\ddot{\mathbf{O}}_{\mathbf{7 9}}$ her dakikada sicaklık artmıştır, $\ddot{\mathbf{O}}_{\mathbf{2 0 9}}$ kaplardaki sular arttıkça sıcaklıklar azalıyor, $\ddot{\mathbf{O}}_{\mathbf{2 0 4}}$ ters orantılı bir ilişki vardır, cevaplarını vermişlerdir.

\section{Oranlı Düşünme Becerisinin Gelişimine İlişkin Bulgular}

Değişkenler arası oranın anlaşılabilmesi ve ilişkilerin karşılaştırılmasında kullanılan zihinsel süreçtir. Bu beceri, herhangi bir olayı etkileyen değişkenler arasında ne tür bir oranın olduğunu algılayabilme ile ilgilidir (Özmen, Çepni Ed., 2011).

Testte oranlı düşünme becerisini ölçmeye yönelik 2 soruya yer verilmiştir. Oranlı düşünme ile ilgili her bir soruya doğru ve yanlış 
cevap veren öğrencilerin sınıflarına göre sayıları ve yüzdelik dağılımları Tablo 11'de verilmiştir.

Tablo 11. Oranlı Düşünme Sorularına Verilen Doğru ve Yanlış Cevapların Sınıf Seviyelerine Göre Dağılımı

\begin{tabular}{ccccccccc}
\hline & \multicolumn{8}{c}{ ORANLI DÜŞÜNME } \\
\hline \multirow{2}{*}{ SINIFLAR } & \multicolumn{9}{c}{ 1.soru } & \multicolumn{3}{c}{ 2.soru } \\
\cline { 2 - 10 } & \multicolumn{2}{c}{ Doğru } & \multicolumn{2}{c}{ Yanlış } & \multicolumn{2}{c}{ Doğru } & \multicolumn{2}{c}{ Yanlış } \\
\hline & $\mathrm{f}$ & $\%$ & $\mathrm{f}$ & $\%$ & $\mathrm{f}$ & $\%$ & $\mathrm{f}$ & $\%$ \\
\hline 4. Sinıf & 1 & 1.4 & 70 & 98.6 & 7 & 9.9 & 64 & 90.1 \\
5. Sinıf & 11 & 14.1 & 67 & 85.9 & 24 & 30.8 & 54 & 69.2 \\
6. Sınıf & 23 & 31.5 & 50 & 68.5 & 31 & 42.5 & 42 & 57.5 \\
7. Sinıf & 47 & 60.3 & 31 & 39.7 & 49 & 62.8 & 29 & 37.2 \\
TOPLAM & 82 & 27.3 & 218 & 72.7 & 111 & 37.0 & 189 & 63.0 \\
\hline
\end{tabular}

Tablo 11 incelendiğinde oranlı düşünme ile ilgili 1. sorunun 4. sinıf öğrencilerinin \% 1.4'ü, 5. sınıf öğrencilerinin \% 14.1'i, 6. sinıf öğrencilerinin \% 31.5'i ve 7. sınıf öğrencilerinin \% 60.3'ü tarafından doğru olarak yanıtlandığı, 2. sorunun ise 4. sınıf öğrencilerinin \% 9.9'u, 5. sinıf öğrencilerinin $\% 30.8^{\prime} i, 6$. sinıf öğrencilerinin $\% 42.5$ 'i ve 7 . sınıf öğrencilerinin \% 62.8'i tarafından doğru olarak yanıtlandığı görülmüştür. Genel olarak değerlendirildiğinde 1. soru öğrencilerin \% 27.3'ü, 2. soru ise \%37'si tarafından doğru olarak cevaplandırılmıştır.

Aşağıda oranlı düşünmeye yönelik sorulan sorulardan birine ve öğrencilerin soruya verdikleri cevaplardan birkaçına yer verilmiştir. 
Soru: Birbirinden farklı büyüklükte 2 dişli çark ile ilgili görsele ilişkin Gizem şekildeki dişli çarklardan büyük çarkı 2 kez çevirdiğinde küçük çarkın 6 kez döndüğünü görüyor. Buna göre küçük çark 18 kez döndüğünde büyük çark kaç kez dönmüş olur?

Sorusuna $\ddot{\mathbf{O}}_{\mathbf{8 8}} 9 \mathrm{kez}$ dönmüş olur, $\ddot{\mathbf{O}}_{\mathbf{8 6}} 22 \mathrm{kez}, \ddot{\mathbf{O}}_{\mathbf{7 8}} 28 \mathrm{kez}, \ddot{\mathbf{O}}_{69} 9$ kez, $\ddot{\mathbf{O}}_{174} 54 \mathrm{kez}, \ddot{\mathbf{O}}_{196}$ aralarındaki ilişki 3 kat olduğundan dolayı 6 kez döner, cevaplarını vermişlerdir.

\section{Ölçülen Beceriler İçin Her İki Soruya Verilen Doğru Cevaplara} İlişkin Bulgular

Becerileri ölçen her iki soruyu da doğru olarak cevaplayan öğrencilerin sınıflarına göre dağılımları Tablo 12'de verilmiştir.

Tablo 12. Becerileri Ölçen Her İki Soruyu Doğru Olarak Cevaplayan Öğrencilerin Sınıf Seviyelerine Göre Dağılımları

\begin{tabular}{|c|c|c|c|c|c|c|c|c|c|c|c|c|c|c|c|c|c|c|}
\hline \multirow[b]{4}{*}{ Siniflar } & \multicolumn{18}{|c|}{ SOYUT İSLEMLER DÖNEMI ÖZZELLIKLERİ } \\
\hline & \multicolumn{4}{|c|}{ Hipotetik } & \multicolumn{6}{|c|}{ Değişkenleri Belirleme } & \multicolumn{2}{|c|}{ Olassliklı } & \multicolumn{2}{|c|}{ Kombinezon } & \multicolumn{2}{|c|}{ Korelasyonel } & \multicolumn{2}{|c|}{ Oranll } \\
\hline & \multicolumn{2}{|c|}{ Araşturma } & \multicolumn{2}{|c|}{ Hipotez } & \multicolumn{2}{|c|}{ Bağmlı } & \multicolumn{2}{|c|}{ Bağımsız } & \multicolumn{2}{|c|}{ Kontrol } & \multirow[b]{2}{*}{ f } & \multirow[b]{2}{*}{$\%$} & \multirow[b]{2}{*}{ f } & \multirow[b]{2}{*}{$\%$} & \multirow[b]{2}{*}{ f } & \multirow[b]{2}{*}{$\%$} & \multirow[b]{2}{*}{ f } & \multirow[b]{2}{*}{$\%$} \\
\hline & f & $\%$ & $\mathrm{f}$ & $\%$ & $\mathrm{~F}$ & $\%$ & $\mathrm{f}$ & $\%$ & $\mathrm{f}$ & $\%$ & & & & & & & & \\
\hline 4. Sinlf & 0 & 0 & 0 & 0 & 0 & 0 & 0 & 0 & 0 & 0 & 1 & 1.4 & 16 & 22.5 & 2 & 2.8 & 1 & 1.4 \\
\hline 5. Sinif & 4 & 5.12 & 2 & 2.5 & 9 & 11.5 & 12 & 15.3 & 11 & 14.1 & 23 & 29.4 & 44 & 56.4 & 14 & 17.9 & 6 & 7.6 \\
\hline 6. Sinff & 7 & 9.5 & 6 & 8.2 & 6 & 8.2 & 5 & 6.8 & 2 & 2.7 & 15 & 20.5 & 40 & 54.7 & 9 & 12.3 & 20 & 27.3 \\
\hline 7. Sinff & 27 & 34.6 & 20 & 25.6 & 26 & 33.3 & 30 & 38.4 & 18 & 23.0 & 38 & 48.7 & 58 & 74.3 & 35 & 44.8 & 38 & 48.7 \\
\hline Toplam & 38 & 12.6 & 28 & 9.3 & 41 & 13.6 & 47 & 15.6 & 31 & 10.3 & 77 & 25.6 & 158 & 52.6 & 60 & 20 & 65 & 21.6 \\
\hline
\end{tabular}


1. Hipotetik Düşünme: Geliştirilen soyut işlemler dönemi beceri testinde hipotetik düşünme becerisi araştırma sorusu oluşturma ve hipotez kurmaya ilişkin sorularla ölçülmüştür.

a) Araştırma Sorusu Oluşturma: Tablo 12 incelendiğinde araştırma sorusu oluşturma ile ilgili her iki soruyu da 4. sınıf öğrencilerinin yanıtlayamadığı, soruların her ikisinin 5. sınıf öğrencilerinin \% 5.12'si, 6. sınıf öğrencilerinin \% 9.5'i ve 7. sinıf öğrencilerinin \% 34.6'sı doğru olarak cevaplandırıldığı görülmüştür. Sınıf seviyeleri arttıkça öğrencilerin soruları doğru olarak cevaplandırma oranlarında bir artış gözlenmektedir.

b) Hipotez Kurma: Tablo 12'ye göre hipotez kurma ile ilgili her iki soruyu da 4. sınıf öğrencileri yanıtlayamazken, 5. sınıf öğrencilerinin $\% 2.5$ 'i, 6. sınıf öğrencilerinin \% 8.2'si ve 7. sinıf öğrencilerinin ise \% 34.6'sı doğru olarak cevaplandırmıştır. Sınıf seviyeleri arttıkça öğrencilerin soruları doğru olarak cevaplandırma oranları artmiştır.

2. Değişkenleri Belirleme ve Tanımlama: Testte değişkenleri belirleme becerisi bağımlı, bağımsız ve kontrol edilen değişkenlere ilişkin sorularla ölçülmüştür.

a) Bă̆ımlı Değişkeni Belirleme: Tablo 12'ye göre bağımlı değişken ile ilgili her iki soruyu da 4. Sınıf öğrencileri yanıtlayamazken, 5. sınıf öğrencilerinin $\% 11.5$ 'i, 6. sınıf öğrencilerinin $\% 8.2$ 'si ve 7 . sınıf öğrencilerinin \% 33.3'ü her iki soruyu doğru olarak cevaplandırmıştır. 
b) Bağımsız Değişkeni Belirleme: Tablo 12'ye göre bağımsız değişken ile ilgili her iki soruyu da 4. sınıf öğrencileri yanıtlayamazken, 5. sinıf öğrencilerinin \% 15.3'ü, 6. sınıf öğrencilerinin \% 6.8'i ve 7 . sınıf öğrencilerinin \% 38.4'ü doğru olarak cevaplandırmıştır.

c) Kontrol Edilen Değişkeni Belirleme: Tablo 12 incelendiğinde kontrol edilen değişkeni belirleme ile ilgili her iki soruyu yine 4. sınıf öğrencilerinin yanıtlayamadığı, soruların 5. sınıf öğrencilerinin \% 14.1'i, 6. sınıf öğrencilerinin \% 2.7'si ve 7. sınıf öğrencilerinin ise \% 23’ü tarafından doğru olarak cevaplandırıldığı görülmüştür.

Her üç değişken için 5. sınıf öğrencilerinin soruları doğru olarak cevaplandırma oranı 6. sınıf öğrencilerine göre daha fazladır.

3. Olasılıklı Düşünme: Tablo 12 incelendiğinde olasılıklı düşünme ile ilgili her iki sorunun 4. sınıf öğrencilerin \% 1.4'ü, 5. sınıf öğrencilerinin \% 29.4'ü, 6. sinıf öğrencilerinin \% 20.5'i ve 7. sinıf öğrencilerinin \% 48.7'si tarafından doğru olarak yanıtlandığı görülmektedir.

4. Kombinezonlu Düşünme: Tablo 12'ye göre kombinezonlu düşünme ile ilgili her iki soruyu 4. sınıf öğrencilerinin \% 22.5'i, 5. sınıf öğrencilerinin \% 56.4'ü, 6. sınıf öğrencilerinin \% 54.7'si ve 7. sinıf öğrencilerinin ise \% 74.3'ü doğru olarak cevaplandırmıştır.

5. Korelasyonel Düşünme: Tablo 12 'ye göre korelasyonel düşünme ile ilgili her iki soruyu 4. sınıf öğrencilerinin \% 2.8'i, 5. sınıf 
öğrencilerinin \% 17.9’u, 6. sinıf öğrencilerinin \% 12.3'ü ve 7. sinıf öğrencilerinin ise $\% 44.8$ 'i doğru olarak cevaplandırmıştır.

6. Oranlı Düşünme: Tablo 12 incelendiğinde oranlı düşünme ile ilgili her iki sorunun 4. sınıf öğrencilerin \% 1.4'ü, 5. sınıf öğrencilerinin \% 7.6's1, 6. sınıf öğrencilerinin \% 27.3'ü ve 7. sınıf öğrencilerinin \% 48.7'si tarafından doğru olarak yanıtlandığı görülmektedir.

Tablo 12'ye göre genel bir değerlendirme yapıldığında çalışmaya katılan 300 öğrenciden 38'i (\% 12.6) araştırma sorularını oluşturabilirken, 28 öğrenci (\% 9.3) hipotezleri kurabilmiştir. 41 öğrenci (\% 13.6) bağımlı değişkenleri, 47 öğrenci (\% 15.6) bağımsız değişkenleri, 31 öğrenci ise (\% 10.3) kontrol edilen değişkenleri doğru olarak belirleyebilmiştir. 77 öğrenci (\% 25.6) olasılıklı düşünme, 158 öğrenci (\% 52.6) kombinezonlu düşünme, 60 öğrenci (\% 20.0) korelasyonel düşünme ve 65 öğrenci (\% 21.6) de oranlı düşünme gerektiren soruları doğru olarak yanıtlamıştır.

Araştırmada elde edilen bulgular değerlendirildiğinde öğrencilerin, soyut işlemler dönemi ile ilgili becerileri gerçekleştirme noktasında yeterli olmadıkları söylenebilir. Bulgulara göre hipotetik düşünme öğrenciler tarafından en düşük oranda gerçekleştirilen beceridir. Sınıf seviyeleri arttıkça hipotetik düşünme becerisinde bir artış gözlenmekle beraber, hipotez kurma ve araştırma sorusu oluşturmada düşük bir yüzdede kalınmıştır.

Değişkenleri belirleme öğrenciler tarafından gerçekleştirilen 2 . en düşük beceridir. Bulgulara göre öğrenciler kontrol edilen değişkeni 
belirlemede, bağımlı ve bağımsız değişkenleri belirlemeye göre daha başarısızdırlar. Ayrıca 5. sınıf öğrencilerinin 6. sınıf öğrencilerine göre değişkenleri belirleme yüzdelerinin daha yüksek olması dikkat çekicidir. 5. sınıf fen ve teknoloji ders kitabı incelendiğinde değişkenlerle ilgili bilgilere yer verildiği görülmüştür. 5. sınıf öğrencilerinin bu bilgiyi henüz öğrenmiş olmaları onların daha başarılı olmasına katkı sağlamış olabilir.

Öğrenciler tarafından gerçekleştirilen 3. en düşük beceri korelasyonel düşünmedir. Bunu sırasıyla oranlı, olasılıklı ve kombinezonlu düşünme takip etmiştir. Oranlı düşünmede sınıf seviyeleri arttıkça öğrencilerin bu becerileri gösterme yüzdelerinde artış görülmektedir. Diğer becerilerde ise yine 5. sınıf öğrencileri 6. sınıf öğrencilerinden daha yüksek bir yüzde göstermişlerdir.

\section{Sonuç, Tartışma ve Öneriler}

Araştırma sonunda elde edilen bulgulara göre öğrencilerin soyut işlemler dönemi ile ilgili becerileri gösterme durumlarının düşük düzeyde olduğu tespit edilmiştir. Bu bulgu araştırmalarında 7. ve 8. sınıf öğrencilerinin çoğunun somut operasyonal dönemde bulunduğu sonucuna ulaşan Kılcal ve Yazgan (2010)'ın bulgularıyla uyuşmaktadır.

Araştırma bulgularına göre öğrencilerin en az gerçekleştirebildikleri beceri hipotetik düşünmedir. Öğrenciler araştırma sorusu oluşturma ve hipotez kurma noktasında sıkıntı yaşamaktadırlar. Hipotez kurma aynı zamanda bilimsel süreç becerilerinin deneysel beceriler bölümünde yer almaktadır. Sinan ve Uşak (2011) biyoloji öğretmen 
adaylarının bilimsel süreç becerilerinin değerlendirilmesi adlı çalışmalarında, öğretmen adaylarının en başarısız olduğu bilimsel süreç becerilerinden birinin hipotez oluşturma ve sınama olduğu, öğrencilerin hipotez kurma yönünden zayıf oldukları bulgusuna ulaşmışlardır. Yine bu bulguda araştırmanın bulgusuyla örtüşür niteliktedir. Ayrıca bu becerinin lisans öğrencilerinde bile düşük düzeyde olması ilköğretimde kazandırılmasının önemini artırmaktadır.

Fen ve teknoloji ders ve öğrenci kitapları incelendiğinde 4. sınıfta 6 etkinlikte, 5 . sinıfta 7 etkinlikte, 6 . sinıfta 11 etkinlikte ve 7 . sinıfta ise 14 etkinlikte araştırma sorularına yer verildiği görülmüştür. Öğrenciden araştırma sorusu oluşturması sadece 6 . sınıfta 1 etkinlikte istenmiştir. Hipotez, 5. sınıf ders kitabında kısaca tanımlanarak 3 etkinlikte oluşturulmuştur. 6. sinıfta 4 ve 7. sinıfta 3 etkinlikte hipotez durumunun verildiği görülmüştür. Yine 6. sınıfta 1 etkinlikte hipotezin öğrenciler tarafından oluşturulması istenmiştir. Bu sonuçlara göre kitaplarda hipotetik düşünme becerisinin gelişmesi için yeterince vurgu yapılmadığ 1 görülmektedir. Özcan ve Oluk (2007) tarafından ilköğretim fen bilgisi dersinde kullanılan soruların analizinin yapıldığı çalışmada hipotetik düşünebilme yeteneğine yönelik soruların oranının \% 1'den daha az olduğu bulgusuna ulaşılmıştır. Bu bulgu hipotetik düşünme becerisinin yazılı soruları ile de desteklenmediğini göstermektedir.

Değişkenleri belirleme hipotetik düşünmeden sonra en az gerçekleştirilen 2. beceridir. Öğrenciler en düşük başarıyı kontrol edilen değişkeni belirlemede göstermişlerdir. 5. sınıf fen ve teknoloji çalışma ve ders kitaplarında 1 etkinlikte değişkenler belirlenmiş, yine 1 etkin- 
likte öğrencilerden değişkenleri belirlemeleri istenmiştir. 6. sınıf kitaplarında 4 etkinlikte değişkenler belirlenmiş olarak verilirken, 1 etkinlikte öğrencilerin belirlemesi istenmiştir. 7. sınıf kitaplarında ise bu becerilerle ilgili etkinliklere yer verilmemiştir. $\mathrm{Bu}$ becerileri geliştirici etkinliklere ders kitaplarında yeterince yer verilmediği görülmektedir.

Öğrenciler tarafindan gerçekleştirilen 3. düşük beceri korelasyonel düşünmedir. Bu beceriyi oranlı, olasılıklı ve kombinezon düşünme takip etmiştir. Çeken ve Ayas (2010) çalışmalarında oranlı düşünmenin fen, matematik ve sosyal bilgiler derslerindeki önemine vurgu yapmışlardır. Aynı çalışmada bu derslerdeki oran ve orantı ile ilgili kazanımların ve ünitelerin zamanlamasında yeterli uyumun sağlanmadığı sonucuna ulaşılmıştır. Oranlı düşünme becerisinin desteklenmesi diğer disiplinler açısından da önem taşınmaktadır.

Öğrencilerin soyut işlemler dönemi becerilerinin geliştirilmesinde öğretmenlere büyük görevler düşmektedir. Öğretmenler öncelikle bilişsel gelişimin ne olduğu, öğrencilerinin hangi gelişim düzeyinde bulunduğu ve bu gelişim düzeyinin gerektirdiği becerilerin neler olduğu hakkında yeterli bilgilere sahip olmalıdırlar. Eğitim-öğretim etkinlikleri planlanırken bu becerilerin gelişimine katkı sağlayacak çalışmalara yer verilmelidir. Simatwa (2010) çalışmasında öğretmenlerin ilköğretim öğrencilerine yönelik yapacağı ders etkinliklerini planlarken, öğrencilerin bilişsel gelişimlerine göre düzenleme yapmalarının gerekli olduğunu belirtmiştir. Öğrencilerin bilişsel dengesizlik yaşadığı durumda, dengelenme durumunun nasıl sağlanabileceğine ilişkin düşüncelere yer verilmiştir. Yine Ojose (2008) yapmış olduğu çalışmada 
matematik öğretiminin uygulamalarını Piaget'in bilişsel gelişim kuramına göre yapmıştır.

Yazılı sorularının öğrencilerden beklenen becerileri destekler nitelikte sorular içermesine özen gösterilmelidir. Fen ve teknoloji ders kitapları incelenerek becerilerin gelişimi noktasında öğrencilere ne kadar katkı sağladığı ortaya konmalıdır.

\section{Kaynakça}

Afacan, Ö. (2011). Fen bilgisi öğretmen adaylarının "fen" ve "fen ve teknoloji öğretmeni” Kavramlarına yönelik metaphor durumları. e-Journal of New World Sciences Academy, 6(1), 1242-1254.

Ayvacı, H. Ş. ve Şahin, Ç. (2009). Fen bilgisi öğretmenlerinin ders sürecinde ve yazılı sınavlarda sordukları soruların bilişsel seviyelerinin karşılaştırılması. Uludă̆ Üniversitesi Eğitim Fakültesi Dergisi, 22(2), 441-455.

Bacanlı, H. (2005). Gelişim ve öğrenme. Ankara: Nobel Yayın Dağ1tım.

Baser, M. (2006). Fostering conceptual change by cognitive conflict based instruction on students' understanding of heat and temperature concepts. Eurasia Journal of Mathematics, Science and Technology Education, 2(2). http://www.ejmste.com.

Büyüköztürk, Ş., Çakmak, E.K., Akgün, Ö. E., Karadeniz, Ş. ve Demirel, F. (2010). Bilimsel Araştırma Yöntemleri. Ankara: Pegem Akademi.

Çakıcı, Y. (2010). Fen eğitiminde yapılandırmacı yaklaşım ve öğrencilerin kavram yanılgıları. Trakya Üniversitesi Sosyal Bilimler Dergisi, 12(1), 89-115. 
Çapri, B. ve Çelikkaleli, Ö. (2005). İlköğretim birinci kademedeki (7-11 yaş grubu) Çocukların korunum gelişim düzeylerinin cinsiyet ve sınıf değişkeni açısından incelenmesi. Mersin Üniversitesi Eğitim Fakültesi Dergisi, 1(1), 48-65.

Çeken, R. ve Ayas, C. (2010). İlköğretim fen veteknoloji ile sosyal bilgiler ders programlarında oran ve orantı. Gaziantep Üniversitesi Sosyal Bilimler Dergisi, 9(3). 669-679. http://sbe.gantep.edu.tr.

Çepni, S. (Ed.). (2011). Kuramdan uygulamaya fen ve teknoloji öğretimi. Ankara: Pegem Akademi.

Çepni, S., Ayas, A., Johnson, D. ve Turgut, F.M. (1997). Fizik Öğretimi, Milli Eğitimi Gelişstirme Projesi, Ankara: YÖK.

Çepni, S., Gökdere, M. ve Özsevgeç, T. (2002). Kimya Sorularının Soyut Operasyon Dönemi Özelliklerine Göre İncelenmesi. $V$. Ulusal Fen Bilimleri ve Matematik Kongresi, 16-18 Eylül, Ankara: ODTÜ.

Fleener, M. J. \& Marek, E.A. (1992). Testing in the learning cycle. Science Scope, 15(6), 48-49.

Kılcal, R. Y. ve Yazgan, A. D. (2010). İlköğretim 7.ve 8. sınıf öğrencilerinin formal operasyonel düşünme becerilerinin bazı değişkenler açısından incelenmesi. İlköğretim Online, 9(2), 723-733. http://ilkogretim-online.org.tr.

Malatyalı, E. ve Yılmaz, K. (2010).Yapılandırmacı öğrenme sürecinde kavramlar ve önemi: Kavramların pedegojik açıdan incelenmesi. Uluslararası Sosyal Araştırmalar Dergisi; The Journal of International Social, Research, 3(14), 320-332.

Marek, E. A., Askey, D. M. \& Abraham, M. R. (2000). Student absences during learning cycle phases: A technological alternative 
for make-up work in laboratory based high school chemistry. International Journal of Science Education, 22(10), 1055-1068.

MEB. (2006). Illköğretim fen ve teknoloji dersi (6, 7 ve 8.sinuflar) $\ddot{O} \breve{g}-$ retim Programı. Ankara.

Ojose, B. (2008). Applying Piaget's theory of cognitive development to mathematics instruction. The Mathematics Educator, 18(1), 26-30.

Ömercikoğlu, H. (2006). 4-7 yaş arası çocukların sayı kavramlarının Piaget'in birebir eşleme deneyleri ile incelenmesi. Yüksek lisans tezi, Marmara Üniversitesi Eğitim Bilimleri Enstitüsü Okul Öncesi Eğitimi Anabilim Dalı.

Ören, F.Ş. ve Tezcan, R. (2009). İlköğretim 7. sınıf fen bilgisi dersinde öğrenme halkası yaklaşımının öğrencilerin tutumları üzerine etkisi. Illkögrretim Online, 8(1), 103-118. http://ilkogretim-online.org.tr.

Özcan, S. ve Oluk, S. (2007). İlköğretim fen bilgisi derslerinde kullanılan soruların Piaget ve Bloom taksonomisine gore analizi. D. Ü.Ziya Gökalp Ĕ̌itim Fakültesi Dergisi, 8, 61-68.

Özsevgeç, T. (2006). Kuvvet ve hareket ünitesine yönelik 5E modeline göre geliştirilen öğrenci rehber materyalinin etkililiğinin değerlendirilmesi. Türk Fen Eğitimi Dergisi, 3(2), 36-48.

Senemoğlu, N. (2011). Gelişim ögrenme ve öğretim kuramdan uygulamaya. Ankara: Pegem Akademi.

Sinan, O. ve Uşak, M. (2011). Biyoloji öğretmen adaylarının bilimsel süreç becerilerinin değerlendirilmesi. Mustafa Kemal Üniversitesi Sosyal Bilimler Enstitüsü Dergisi, 8(15), 333-348.

Simatwa, E. M. W. (2010). Piaget's theory of intellectual development 
and its implication for instructional management at presecondary school level. Educational Research and Reviews, 5(7), 366-371.

Şimşek, C. L. (2007). Illköğretim ögrencilerinin temel fen kavramları ile ilgili düşünceleri. Doktora tezi, Gazi Üniversitesi Eğitim Bilimleri Enstitüsü.

Türkmen, H. ve Usta, E. (2007). Öğrenme döngüsü yaklaşımının fendeki kavram yanılgılarının giderilmesindeki rolü. Kastamonu Eğitim Dergisi, 15(2), 491-500.

Yıldırım, A. ve Şimşek, H. (2008). Sosyal bilimlerde nitel araştırma yöntemleri. Ankara: Seçkin Yayıncılık. 


\title{
EK:Soyut İşlemler Dönemi Beceri Testi (SİDBT) (Örnek Sorular)
}

\author{
1. Hipotetik Düşünme
}
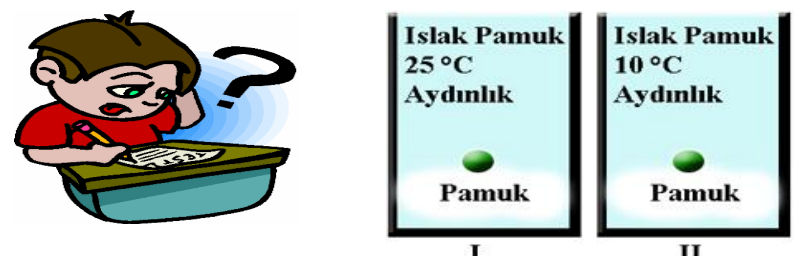

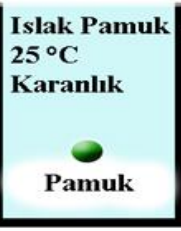

III
Kuru Pamuk $25^{\circ} \mathrm{C}$

Karanlık

Pamuk

Ahmet çimlenme için gerekli olan şartları araştırmak istemiş ve yukarıdaki düzenekleri hazırlamış̧ır. Ahmet'in amacına ulaşabilmesi için oluşturacağı araştırma soruları, geliştireceği hipotezler ve kullanacağı düzenekler neler olmalıdır, bir tanesini yazınız?

\begin{tabular}{|l|l|}
\hline Araştırma Sorusu & Hipotez \\
\hline $1-$ & \\
\hline
\end{tabular}

2. Değişkenleri Belirleme ve Tanımlama

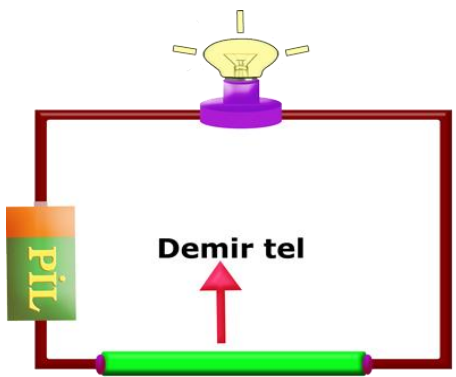

Şekil 1

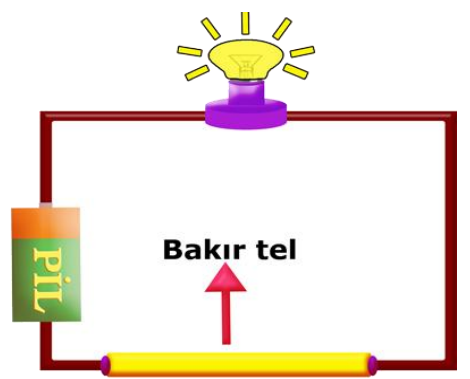

Şekil 2

Eren, şekildeki elektrik devrelerinde özdeş ampul, pil ve kablolar kullanmıştır. Şekil 1'deki devrede kontrol uçları arasına demir tel, şekil 2'deki devrede ise kontrol uçları arasına bakır tel takıp ampullerin parlaklığını gözlemlenmiştir.

Eren'in deneydeki bağımlı, bağımsız ve kontrol edilen değiş̧kenleri belirleyiniz.

Bağımlı Değişken

Bağımsız Değişken 


\section{Kontrol Edilen Değişken}

\section{Olasılıklı Düşünme}
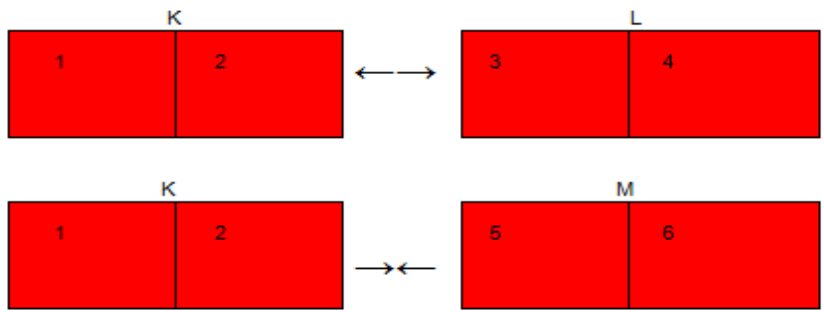

M

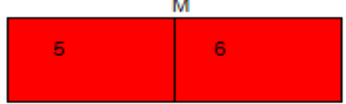

?

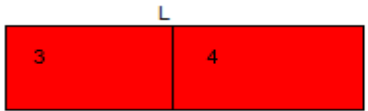

Zeynep kutuplarını bilmediği $\mathrm{K}, \mathrm{L}$, ve $\mathrm{M}$ mıknatıslarını şekildeki gibi birbirlerine yaklaştırdığma $\mathrm{K}$ ve L'nin birbirini ittiğini; $\mathrm{K}$ ve M'nin ise çektiğini görüyor. Buna göre; $\mathrm{M}$ ve L miknatısları birbirlerine yaklaştırdığında etkileşimleri nasıl olur? Açıklayınız.

\section{Kombinezonlu Düșünme}

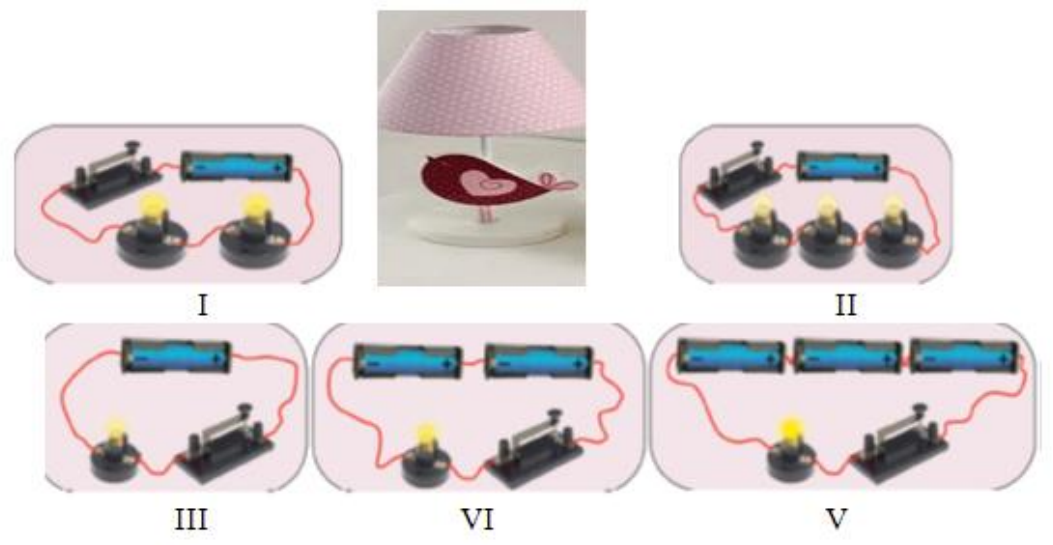

Merve, Fen ve Teknoloji dersinde performans görevi için bir gece lambası tasarlayacaktır. Gece lambasımın çok ş̧ık vermesini isteyen Merve, yukarıdaki düzeneklerden hangisini kullanmalıdir?

(Ampul, pil ve kablolar özdeştir.) 
5. Korelasyonel Düșünme

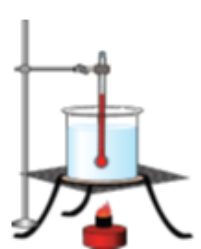

( 200ml su )

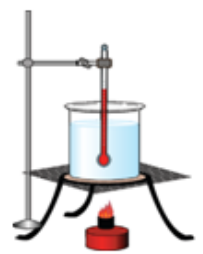

(150ml su )

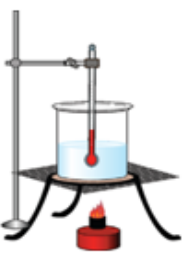

(100ml su)

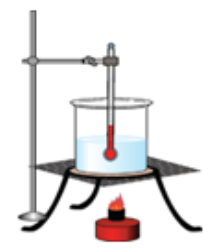

(50 ml su)

1- Çağrı, ilk sıcaklikları aynı olan farklı miktardaki suları beherglaslara koyup özdeş 1sitıcılarla 1sıtmaya başlamış ve belirli aralıklarla sıcaklık değişimlerini ölçüp aşağıdaki tabloya kaydetmiştir.

4

\begin{tabular}{|l|l|l|l|l|}
\hline & $\begin{array}{l}\text { İlk } \\
\left.\text { sicaklık( }{ }^{\circ} \mathrm{C}\right)\end{array}$ & $\begin{array}{l}2 \text { dk. Sonra } \\
\left.\text { Sicaklık( }{ }^{\circ} \mathrm{C}\right)\end{array}$ & $\begin{array}{l}4 \text { dk. Sonra } \\
\left.\text { Sicaklık( }{ }^{\circ} \mathrm{C}\right)\end{array}$ & $\begin{array}{l}6 \text { dk. sonra } \\
\left.\text { Sıcaklık( }{ }^{\circ} \mathrm{C}\right)\end{array}$ \\
\hline $50 \mathrm{ml}$ su & 15 & 26 & 37 & 48 \\
\hline $100 \mathrm{ml}$ su & 15 & 21 & 27 & 33 \\
\hline $150 \mathrm{ml}$ su & 15 & 19 & 23 & 27 \\
\hline $200 \mathrm{ml}$ su & 15 & 17 & 19 & 21 \\
\hline
\end{tabular}

Tablodaki bilgilere göre su miktarları ile sıcaklık değişimi arasında nasıl bir ilişki vardır? 


\section{Oranlı Düșünme}

1-

Denge I. II.

Durumu mum Durum. Durum
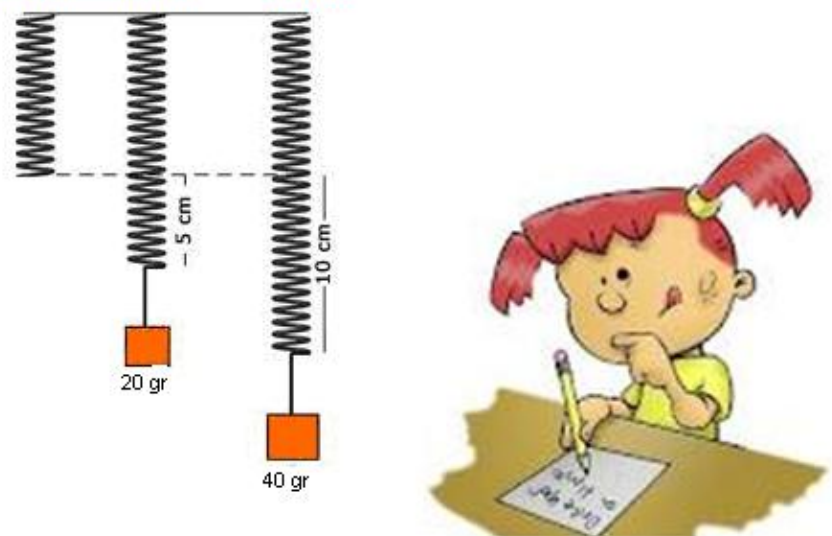

Aslı oyuncak arabasının içinden çıkardığ1 $15 \mathrm{~cm}$ uzunluğundaki yaya $20 \mathrm{gr}$ lik $^{\prime}$ ağırlik taktığında yaym $5 \mathrm{~cm}, 40$ gr'lik ağıllik taktığında ise $10 \mathrm{~cm}$ uzadığını görüyor. Buna göre;

a) Aslı yayına 50 gr'lık ağrllık taksaydı yay 1 kaç $\mathrm{cm}$ uzardı? 